\title{
Whitemouth croaker, Micropogonias furnieri, trapped in a freshwater coastal lagoon: a natural comparison of freshwater and marine influences on otolith chemistry
}

\author{
Cristiano Q. de Albuquerque ${ }^{1}$, Norbert Miekeley ${ }^{2}$ and José H. Muelbert ${ }^{1}$
}

\begin{abstract}
Strontium and barium incorporation into otoliths was compared between whitemouth croaker, Micropogonias furnieri, collected from an entrapped freshwater population (Mirim Lagoon) and a normal marine/estuarine population in southern Brazil. Chemical analysis was performed using LA-ICPMS with the objective of validating the effects of marine and freshwater environments on $\mathrm{Sr}$ and $\mathrm{Ba}$ incorporation as a basis for further investigation of marine and freshwater connectivity of $M$. furnieri. The freshwater population was dominated by older fish with mean \pm SD age of $34 \pm 1 \mathrm{y}$, whereas the coastal samples were dominated by younger fish of $14 \pm 7 \mathrm{y}$. Comparison of strontium and barium incorporation among otolith life-history profiles indicated significantly higher barium and lower strontium for the freshwater population compared to the marine population. Furthermore, comparison of otolith material deposited in the freshwater, estuarine and marine life-history phases demonstrated clear differences among these environments. Mean concentrations of strontium and barium in otoliths of $M$. furnieri were respectively 710 and $112 \mu \mathrm{g} \mathrm{g}^{-1}$ for freshwater, 2069 and $16.7 \mu \mathrm{g} \mathrm{g}^{-1}$ for estuarine, and 2990 and $2.7 \mu \mathrm{g} \mathrm{g}^{-1}$ for marine life-history phases. Barium concentrations in otoliths from the freshwater population of $M$. furnieri appeared high relative to other freshwater species. Strontium levels across life-history profiles of marine fish increased with age from 2000 to $2900 \mu \mathrm{g} \mathrm{g}^{-1}$, possibly indicating more time spent in marine than estuarine waters with age. In contrast, for the freshwater population, strontium levels decreased during the first year of life approximately to $700 \mu \mathrm{g} \mathrm{g}^{-1}$, and remained low and stable thereafter, consistent with the early life-history occurring in an estuarine environment prior to entrapment in Mirim Lagoon. The results confirm the strong and opposite effects of marine and freshwater environments on incorporation of barium and strontium into otoliths, and indicate that the population of $M$. furnieri in Mirim Lagoon represents an isolated population that does not reproduce and is therefore likely to become extinct.
\end{abstract}

Estrôncio e bário foram determinados em otólitos de corvina Micropogonias furnieri coletados em habitats de água doce (lagoa Mirim) e costeiros no Sul Brasil. As análises foram realizadas utilizando-se LA-ICPMS, com o objetivo de estabelecer assinaturas químicas específicas para os diferentes habitats e avaliar a aplicabilidade da química de otólitos para o estudo de mudanças de habitat na espécie em questão para futuros estudos sobre conectividade de populações. Os animais coletados na lagoa Mirim apresentaram idade média de $34 \pm 1$ anos, não sendo observados adultos jovens ou juvenis. Foi verificada uma variação significativa nas concentrações de Sr e Ba em otólitos para áreas marinhas e de água doce. Para ambientes marinhos, a idade média foi de $14 \pm 7$ anos. Os valores médios de $\mathrm{Sr}$ e Ba foram estimados, respectivamente, em 710 e $112 \mu \mathrm{g} \mathrm{g}^{-1}$ para água doce, 2069 e 16,7 $\mu \mathrm{g} \mathrm{g}^{-1}$ para água estuarina e 2990 e 2,7 $\mu \mathrm{g} \mathrm{g}^{-1}$ para águas costeiras. Nos otólitos provenientes dos indivíduos de água doce, o Ba apresentou concentrações mais altas quando comparado a valores observados para outras espécies. Observou-se que a incorporação de Ba nos otólitos ao longo da vida sofre certa influência ontogenética, com valores mais altos medidos no início da vida. As concentrações de Sr em otólitos de animais costeiros aumentaram em média de 2000 a $2900 \mu \mathrm{g} \mathrm{g}^{-1}$ ao longo da vida, indicando a mudança de habitats estuarinos para marinhos. Para água doce, a concentração de Sr decresce antes do primeiro ano até valores em torno de $700 \mu \mathrm{g} \mathrm{g}^{-1}$ mantendo essa concentração por toda a vida, indicando um ambiente de água doce estável. Estes resultados confirmam o forte efeito inverso que ambientes marinhos e de água doce promovem na incorporação de Sr e Ba em otólitos e permitem sugerir que a corvina encontrada na lagoa Mirim é representada por um grupo isolado de animais com baixa probabilidade de reprodução que, portanto, será possivelmente extinto nos próximos anos.

Key words: Strontium, Barium, Laser ablation, ICPMS, Life-history, Population extinction.

\footnotetext{
${ }^{1}$ Institute of Oceanography, Universidade Federal do Rio Grande. Av. Itália, Km 8, Caixa Postal 474, 96201-900 Rio Grande, RS, Brazil. doccqa@yahoo.com.br

${ }^{2}$ Department of Chemistry, Pontifícia Universidade Católica do Rio de Janeiro. Rua Marquês de São Vicente, 225, Gávea, $22453-900$ Rio de Janeiro, RJ, Brazil.
} 


\section{Introduction}

Whitemouth croaker (Micropogonias furnieri Desmarest) is an eurihaline sciaenid widely distributed along the eastern coast of the Atlantic Ocean, occurring from the Gulf of Mexico to the Gulf of San Matías (Argentina). It is an important fishery resource for Brazil, Uruguay and Argentina (Lasta \& Acha, 1996; Vasconcellos \& Haimovici, 2006). Spawning has been reported in coastal and estuarine waters (Macchi et al., 1996; Acha et al., 1999; Jaureguizar et al., 2008), and juveniles are commonly caught in Patos Lagoon estuary during the entire year (Castello, 1986). This species has been caught in the Mirim Lagoon (Fig. 1), despite more than 30 years of isolation from estuarine waters (Burns et al., 2006). The Patos-Mirim Lagoon complex is an oligohaline-freshwater ecosystem and its southern area experiences the high variability of salinity characteristic of estuarine waters (Seeliger, 2001). During summer, Patos Lagoon estuary commonly receives large inputs of saltwater, which are enhanced when there is an association to low pluviometric levels and predominance of SE wind (Castello \& Möller, 1978). Sometimes these saltwater intrusions reach the São Gonçalo channel, which is the unique communication between Patos and Mirim Lagoons (Fig. 1). To avoid damages to the rice farms in this region, Brazilian and Uruguayan governments have constructed a floodgate on São Gonçalo channel in 1977 to control saltwater intrusion. Since then, the Mirim Lagoon has been characterized as a freshwater environment. Salinity variability of the Patos Lagoon estuary and Mirim Lagoon has been presented by Burns et al. (2006).

Some ecological questions about $M$. furnieri inhabiting this system remain unanswered. For example, when did these fish enter the lagoon? Would the floodgate be able to prevent fish movements between Patos Lagoon estuary and Mirim Lagoon? And, is it possible that the group in Mirim Lagoon is self-replenishing? We aim to answer these questions using the chemical information stored in the otoliths of $M$. furnieri.

Otoliths, or ear stones, are complex polycrystalline structures composed by calcium carbonate and organic template that develop inside the inner ears of teleost fish (Lenaz et al., 2006). Ever since yearly and daily micro-increment structures were described and validated in otoliths (Reisbish, 1899; Pannela, 1971) they have been used extensively as fish ageing tools in fisheries and fish ecology research (i.e. Castello, 1986; Hoolihan, 2006; Albuquerque et al., 2009). In the last two decades, a new and powerful approach for otolith studies has emerged: the association of time-preserving properties of otoliths to the environmental conditions experienced by fish throughout their life (Radtke, 1984; Campana, 1999). Otoliths are metabolically inert structures that preserve a chronology of chemical variation, some of which is related to the environmental history of the fish. Due to these attributes, some aspects of the environmental history of fish can be inferred from chemical variation within the otoliths (Campana \& Neilson, 1985; Fowler et al., 1995a). Variation of incorporation of strontium, barium, and potentially other trace metals into otoliths can at least partly reflect spatial and temporal changes in the physico-chemical properties of the water experienced by the fish (Fowler et al., 1995a; Gillanders, 2005).

In general, $\mathrm{Sr}$ and $\mathrm{Ba}$ concentrations in otoliths increases according to their availability in the water (Bath et al., 2000; Elsdon \& Gillanders, 2002). It is common that strontium concentrations in water increase towards saltwater and barium concentrations increase towards freshwater (Surge \& Lohmann, 2002; Jacquet et al., 2005). Therefore, for a given species higher strontium concentrations should be deposited in otoliths of fish living in higher salinity waters, and higher barium in otoliths from fish living in freshwater environments (i.e. Campana, 1999). Extrapolation of previously published relationships between salinity variation and variation of barium and strontium incorporation into otoliths (see review Gillanders, 2005) are dependent on the assumption that the ambient concentrations of these elements in the water are consistently correlated with salinity. Furthermore, relationships between water chemistry and otolith chemistry observed for one species may not necessarily be generalized across other species (Gillanders \& Kingsford, 2003; Swearer et al., 2003; Hamer \& Jenkins, 2007) and other factors such as water temperature, ontogeny and growth may also interact with the influence of salinity on Sr incorporation into otoliths (Fowler et al., 1995a, 1995b; Rooker et al., 2002). Therefore, in order to confidently infer environmental (i.e. salinity) or migratory histories from otolith chemistry for a particular species in a particular system it is essential that preliminary studies confirm the relationships between local salinity variation and strontium and barium variation in otoliths of the species of interest.

The Patos-Mirim Lagoon complex presents an ideal situation for a natural comparison to validate the influence of exposure to fresh, estuarine and marine waters on the otolitth chemistry of $M$. furnieri. This species in the Mirim Lagoon (freshwater) inhabits an environment with no salinity variability for the last 30 years, while its counterparts in the estuary and adjacent marine coast are currently influenced by typical marine and estuarine variation. We aim to evaluate if the analysis of strontium and barium would be useful to determine $M$. furnieri movements along the Patos-Mirim Lagoons systems. More specifically, we aim to provide reference strontium and barium concentrations in otoliths of $M$. furnieri for fresh, estuarine and marine waters, the time of fish entrance to the Mirim Lagoon, and evaluate the existence of movements between these diverse environments.

\section{Material and Methods}

Ten adult $M$. furnieri were sampled in December 2005 in the north area of the Mirim Lagoon (Fig. 1) with a 300-m long gillnet, with various mesh sizes. Fish specimens were randomly sub-sampled from the total capture. Another ten adults were obtained from commercial fisheries in the coastal Rio Grande area at the same time. All sampled specimens were measured for total length and sagittal otoliths were extracted, cleaned and stored dry. The left otoliths were then embedded in epoxy 
resin and transverse sections were cut with a low-speed diamond blade saw as close to the core as possible. Thin sections $(0.4 \mathrm{~mm})$ were mounted onto glass slides using fast drying glue. Prior to laser ablation inductively coupled plasma mass spectrometry (LA-ICPMS) analysis, otolith surfaces were polished with silicon carbide paper $\left(\mathrm{n}^{\circ} 8000\right)$, washed with deionized (DI) water (Milli-Q, Millipore, Bedford, USA), sonicated for 3 minutes, and rinsed three times with DI water. The slides were dried in a horizontal flow cabinet before analysis.

Analytical measurements were performed with a Nd:YAG CETAC LSX 100 Laser Ablation system operating at $266 \mathrm{~nm}$, coupled to an ELAN 5000 (PerkinElmer - SCIEX) inductively coupled plasma-mass spectrometer. The laser was configured for Q-switched mode operation and operated at a pulse frequency of $20 \mathrm{~Hz}$. The laser moved across the otolith at $40 \mu \mathrm{m} \mathrm{s}^{-1}$, with a beam energy of 0.6-0.8 mJ. Under these experimental conditions, the ablated crater width on otoliths was about $30 \mu \mathrm{m}$.

The measured isotopes (masses) were ${ }^{43} \mathrm{Ca},{ }^{86} \mathrm{Sr}$ and ${ }^{138} \mathrm{Ba}$. Analytical quantification was performed in the external calibration mode using a series of matrix matched in-house standards. These standards were comprised of pressed powder $\mathrm{CaCO}_{3}$ discs with known analyte concentrations (for Sr: 520; 986; 1827; 3720; 4400; and $5204 \mu \mathrm{g} \mathrm{g}^{-1}$. For Ba: 4.0; 7.4; 14.0; 28.9; 51.5; and $104.8 \mu \mathrm{g} \mathrm{g}^{-1}$ ), and similar discs of suprapur $\mathrm{CaCO}_{3}$ were used as a blank (further details in Belotto \& Miekeley, 2000; 2007). Measured signals (counts per second - cps) for ${ }^{86} \mathrm{Sr}$ and ${ }^{138} \mathrm{Ba}$ were normalized with reference to ${ }^{43} \mathrm{Ca}$ for correction of the bias induced by differences in the amount of ablated material. Limits of detection (LOD, 3s), determined from the blank discs and the calibration curves from the in-house standards, were $0.46 \mu \mathrm{g} \mathrm{g}^{-1}$ for barium and $5.31 \mu \mathrm{g} \mathrm{g}^{-1}$ for strontium. All concentrations were expressed as micrograms of Ba or Sr per gram of otolith material.

Each otolith section was scanned from the core to the edge. In order to improve the accuracy of the measurements, otoliths were randomly analyzed and a blank profile (without laser) was conducted after each otolith profile. The laser chamber was purged for $60 \mathrm{~s}$ prior to each new otolith analysis to clean the chamber of residual aerosol from the previous ablation.

After chemical analysis, otoliths were photographed under a microscope. Otolith images were measured using the UTHSCSA ImageTool programme (University of Texas Health Science Center at San Antonio, Texas, ftp://

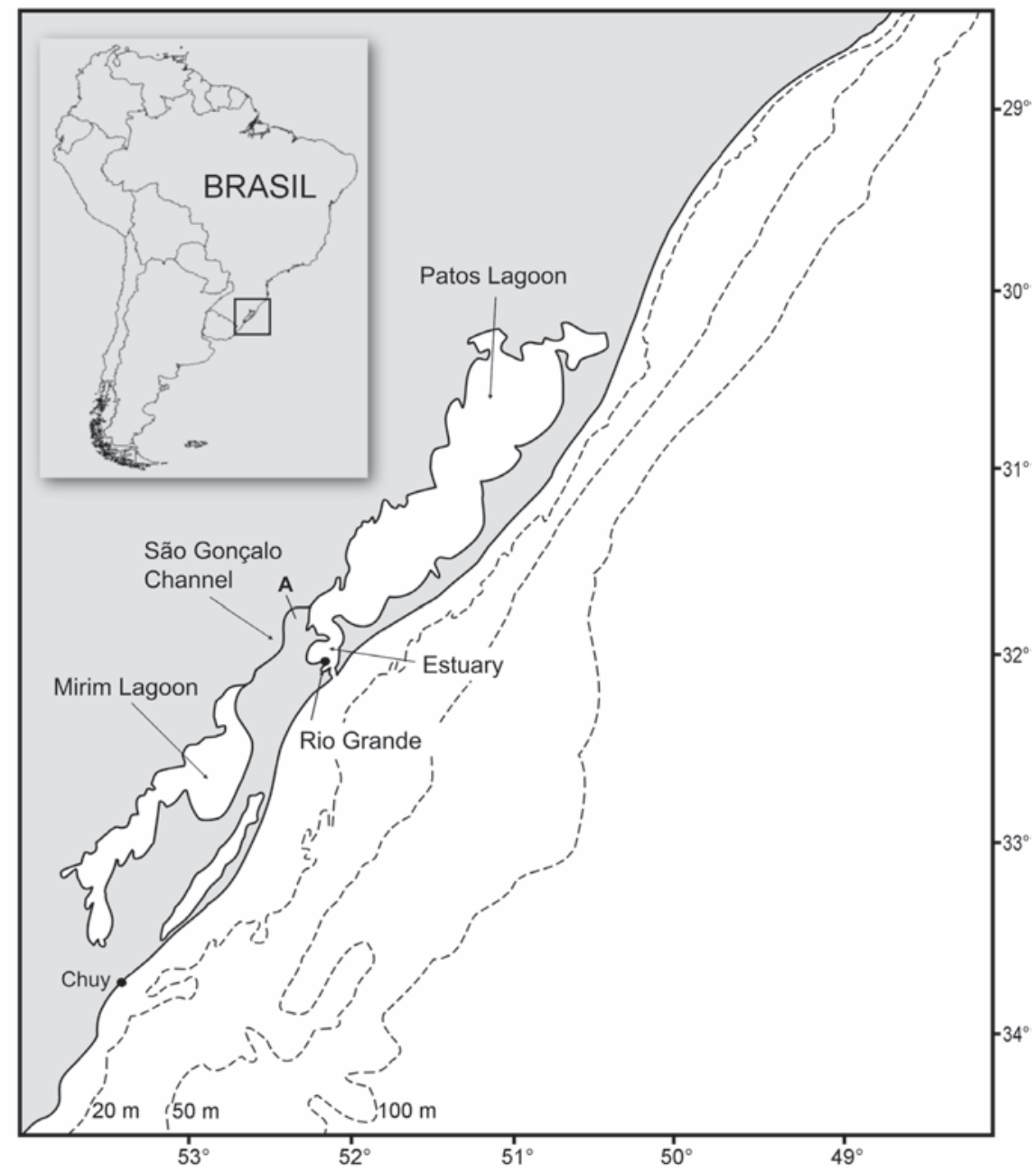

Fig. 1. Sampling area at South Brazil. A = floodgate of São Gonçalo Channel. 
maxrad6.uthscsa.edu) in order to assign ages to specific locations of the life-history profile. The annual pattern of growth increment deposition has been validated (Schwingel \& Castello, 1990).

\section{Model assumptions and statistical analysis}

Whitemouth croaker from the coastal area commonly spend their initial life at estuarine environments and move to the adjacent marine waters, where they live as adults, reproducing close to estuaries (Vazzoler, 1975; Vazzoler et al., 1999). Therefore, statistical comparisons were made regarding integrated concentrations for the first year of life (FYL) and for the last year of life (LYL). Differences in average concentrations of strontium and barium were analyzed between sampling areas and time of life using one-way ANOVA and Tukey HSD post hoc test. In order to satisfy the assumptions of normality and homogeneity of variances, both variables were log-transformed according to $\log _{10}(x+1)$. Significance was attributed at $P<0.05$. Trends in strontium across the life-history were assessed using linear correlation and trends were considered significant if the relationship between distance from core and Sr had an $r>0.7$.

In order to infer fresh, estuarine and marine water signals to otolith composition, we assume that all collected $M$. furnieri had their larval and initial juvenile phase in the estuary of Patos Lagoon. This assumption is supported by data from literature (eg. Castello, 1986; Muelbert \& Weiss, 1991). Therefore, estuarine chemical signature was inferred from strontium and barium concentrations measured for the FYL region for otoliths from fish collected in the ocean. Marine and the freshwater signatures on otoliths were determined for the LYL assuming that fish spent the last year in coastal areas (for marine fish) and in freshwater (for freshwater fish).

\section{Results}

Fish obtained from the Mirim Lagoon were significantly smaller $(41.7 \pm 3.2 \mathrm{~cm})$ than fish collected from the coast of Rio Grande $(60.7 \pm 7.2 \mathrm{~cm})$. However, mean ages were significantly higher, and less variable, in fish from Mirim Lagoon ( $34.3 \pm 1.1 \mathrm{y})$ than from Rio Grande $(14.1 \pm 6.7 \mathrm{y})$.

Strontium mean concentration presented diverse trends and values between the sampled areas. The general pattern shows higher strontium concentrations in otoliths from marine than from freshwater fish (Fig. 2). For marine fish, strontium concentrations for FYL ranged from 1845 to $2300 \mu \mathrm{g} \mathrm{g}^{-1}$ and were significantly lower than mean concentrations for LYL, which ranged from 2175 to $4180 \mu \mathrm{g} \mathrm{g}^{-1}$ (Fig. 2, ANOVA, $P<0.05$ ). For otoliths from freshwater fish, the inverse occurred, with mean strontium concentrations for FYL ranging from 632 to $967 \mu \mathrm{g} \mathrm{g}^{-1}$ and for LYL ranging from 642 to $851 \mu \mathrm{g} \mathrm{g}^{-1}$. Despite major overlap of values between these two groups, the differences were significant (ANOVA, $P<0.05$ ). Strontium concentrations measured along the life-history profiles of otoliths from freshwater fish presented a stable and flat pattern almost through the complete life-history, but with an increase of
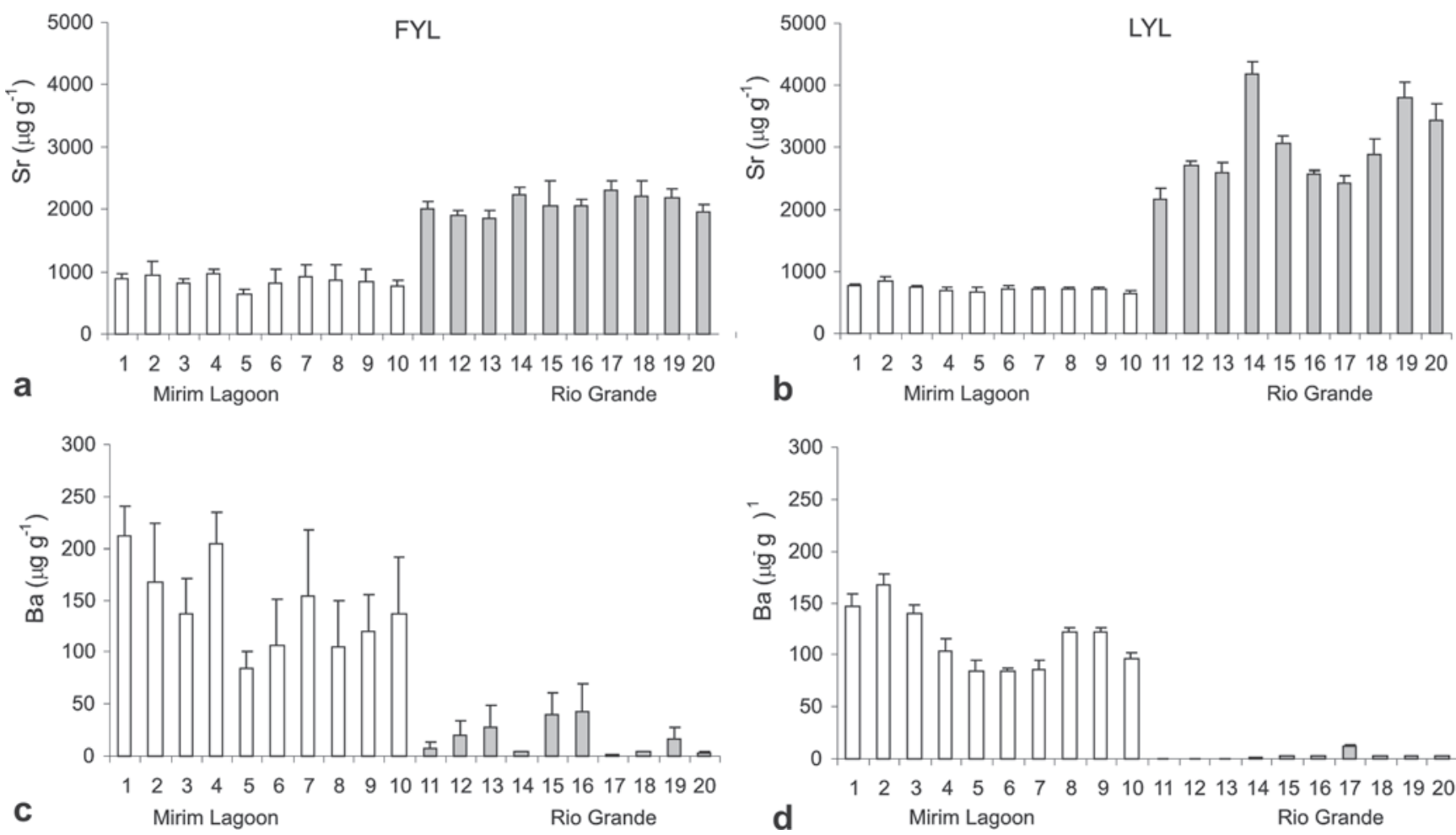

Fig. 2. Strontium mean concentrations for the first (a) and last (b) year of life and barium mean concentrations for the first (c) and last (d) year of life for Micropogonias furnieri individual otoliths from the Mirim Lagoon (white bars) and coastal Rio Grande (grey bars). Error bars indicate standard deviation. 
concentration observed at the beginning of the FYL region (Fig. 3). Except for otolith number 5, all otoliths from freshwater fish presented significant higher strontium concentrations at FYL than at LYL (Fig. 2). The uniform patterns observed in the strontium curves for fish from freshwater were not observed in fish from saltwater, where the concentrations increased significantly with distance from core $(\mathrm{r}>0.75, \mathrm{n}=$ 9). Mean \pm sd strontium values were determined as $2990 \pm$ $635 \mu \mathrm{g} \mathrm{g}^{-1}$ for marine, $2069 \pm 238 \mu \mathrm{g} \mathrm{g}^{-1}$ for estuarine and 710 and $112 \mu \mathrm{g} \mathrm{g}^{-1}$ for freshwater habitats.

Barium patterns showed an inverse trend from that found for strontium, with higher concentrations measured close to the core. FYL presented higher barium concentrations than LYL for freshwater and marine fish. For freshwater fish, barium ranged from 83 to $211{\mu g^{-1}}^{-1}$ for FYL and from 83 to $167 \mu$ g g$^{-1}$ for LYL. Otoliths from marine fish displayed mean concentrations ranging from 0.6 to $42 \mu \mathrm{g} \mathrm{g}^{-1}$ for FYL and $<0.46$ to $11.8 \mu \mathrm{g} \mathrm{g}^{-1}$ for LYL. For most freshwater individuals, the otolith core displayed barium concentrations above $100 \mu \mathrm{g} \mathrm{g}^{-1}$ (Fig. 4). Barium profiles for freshwater fish displayed a peak around the otolith core that was extended to about the first year for freshwater fish and restricted to the core for marine fish. For freshwater fish, these peaks reached almost $300 \mu \mathrm{g} \mathrm{g}^{-1}$, declined to about $100 \mu \mathrm{g} \mathrm{g}^{-1}$ after about 5 years, and remained at approximately this concentration for the rest of the life-history. For marine fish, maximum barium concentration reached about $40 \mu \mathrm{g} \mathrm{g}^{-1}$ and displayed a decline before the first year to levels sometimes below $0.46 \mu \mathrm{g} \mathrm{g}^{-1}$ (Fig. 4). In general, barium profiles presented a similar pattern within habitats, with main differences related to the peak intensity, and the absence of a peak for one otolith. Mean \pm SD barium values for otoliths of freshwater fish were $111.6 \pm 30 \mu \mathrm{g} \mathrm{g}^{-1}$, which contrasted with the much lower values of otoliths from the marine habitat (2.7 $\pm 3.3 \mu \mathrm{g} \mathrm{g}^{-1}$ ). Barium mean value for estuarine fish were estimated at $16.7 \pm 1.6 \mu \mathrm{g} \mathrm{g}^{-1}$ (Fig. 5).

\section{Discussion}

\section{General chemical patterns}

Otoliths from trapped freshwater $M$. furnieri displayed strontium concentrations that were approximately 2 to 4 times lower than those from marine fish. In contrast, barium concentrations in otoliths from trapped freshwater $M$. furnieri were up to 100 times higher than those from marine fish. Our results for otoliths of $M$. furnieri are consistent with previous studies that have reported otolith strontium and barium variations as an indicator of water salinity (e.g. Secor \& Rooker, 2000; Elsdon \& Gillanders, 2002; Vries et al., 2005; Hamer et al., 2006; Martin \& Wuenschel, 2006). In marine waters, concentration of barium is lower than estuarine or freshwater and controlled by barite $\left(\mathrm{BaSO}_{4}\right)$ precipitation (Jacquet et al., 2005). Due to this fact and the higher solubility of strontium in sulfate-rich environments (e.g. ocean water), the partitioning of strontium between water and otolith (and also other carbonate-like structures: e.g. corals and mussel shells) is favored while barium displays the inverse trend.

The ranges of barium and strontium in otoliths for the last year of life of $M$. furnieri sampled in Mirim Lagoon and marine waters can be used as reference values for future studies to infer freshwater/marine life-history movement patterns of this species in this system. Furthermore, because previous studies confirm that the early life of this species is spent in estuaries (Sinque \& Muelbert, 1997; Acha et al., 1999; Jaureguizar et al., 2003), the ranges of barium and strontium in the first year of the otoliths can potentially be used as reference values for inferring movement to and from the estuarine environment. Many studies have reported $\mathrm{Sr}$ and $\mathrm{Ba}$ concentrations in otoliths of fish from freshwater, estuarine and marine environments and the concentrations reported by these previous studies are similar to our results for $M$. furnieri, except for the relatively high barium concentrations we observed for samples from Mirim Lagoon (Table 1). The relatively high otolith barium values detected here for freshwater (Mirim Lagoom) M. furnieri could be related to exceptionally high barium concentrations in that environment or possibly interspecific differences in incorporation rates (Gillanders \& Kingsford, 2003; Swearer et al., 2003; Hamer \& Jenkins, 2007). We have not measured ambient concentrations of barium and strontium throughout the study system nor have we compared barium concentrations for $M$. furnieri otoliths from other freshwater environments. This information would be necessary in order to determine if the relatively high barium concentrations found for freshwater $M$. furnieri are a species-specific effect or are induced by locally high ambient concentrations in Mirim Lagoon.

Table 1. Strontium and barium concentrations $\left(\mu \mathrm{g} \mathrm{g}^{-1}\right)$ measured for otoliths of different species and environments. Campana et al. (1999) presents a synthesis of many studies of earlier years.

\begin{tabular}{|c|c|c|c|c|c|c|c|}
\hline \multirow[b]{2}{*}{ Author } & \multirow[b]{2}{*}{ Species } & \multicolumn{2}{|c|}{ Ocean } & \multicolumn{2}{|c|}{ Estuaries } & \multicolumn{2}{|c|}{ Freshwater } \\
\hline & & $\mathrm{Sr}$ & $\mathrm{Ba}$ & $\mathrm{Sr}$ & $\mathrm{Ba}$ & $\mathrm{Sr}$ & $\mathrm{Ba}$ \\
\hline Campana et al., 2007 & Sebastes mentella & $1600-2400$ & $1.7-2.5$ & & & & \\
\hline Secor et al., 2002 & Thunnus thynnus & $1600-2800$ & $0.6-1$ & & & & \\
\hline Secor et al., 2001 & Morone saxatilis & $2100-2500$ & $3-7$ & $1800-2400$ & $1.8-8$ & $500-900$ & $5-8$ \\
\hline Rooker et al., 2003 & Thunnus thynnus & $1300-1500$ & $1-2$ & & & & \\
\hline Gillanders \& Kingsford, 2000 & Pelates sexlineatus & & & $1500-5000$ & $1-45$ & & \\
\hline Brazner et al., 2004 & Perca flavescens & & & & & $150-500$ & $5-70$ \\
\hline Veinott \& Porter, 2005 & Salmo salar & & & & & $180-1000$ & $3-10$ \\
\hline Volpedo \& Cirelli, 2006 & Micropogonias furnieri & $1500-3500$ & & & & & \\
\hline Campana et al., 1999 & Various & $2137 \pm 127$ & $3.7 \pm 0.6$ & $1937 \pm 70$ & $8.2 \pm 2.7$ & $698 \pm 111$ & $11 \pm 2.8$ \\
\hline
\end{tabular}




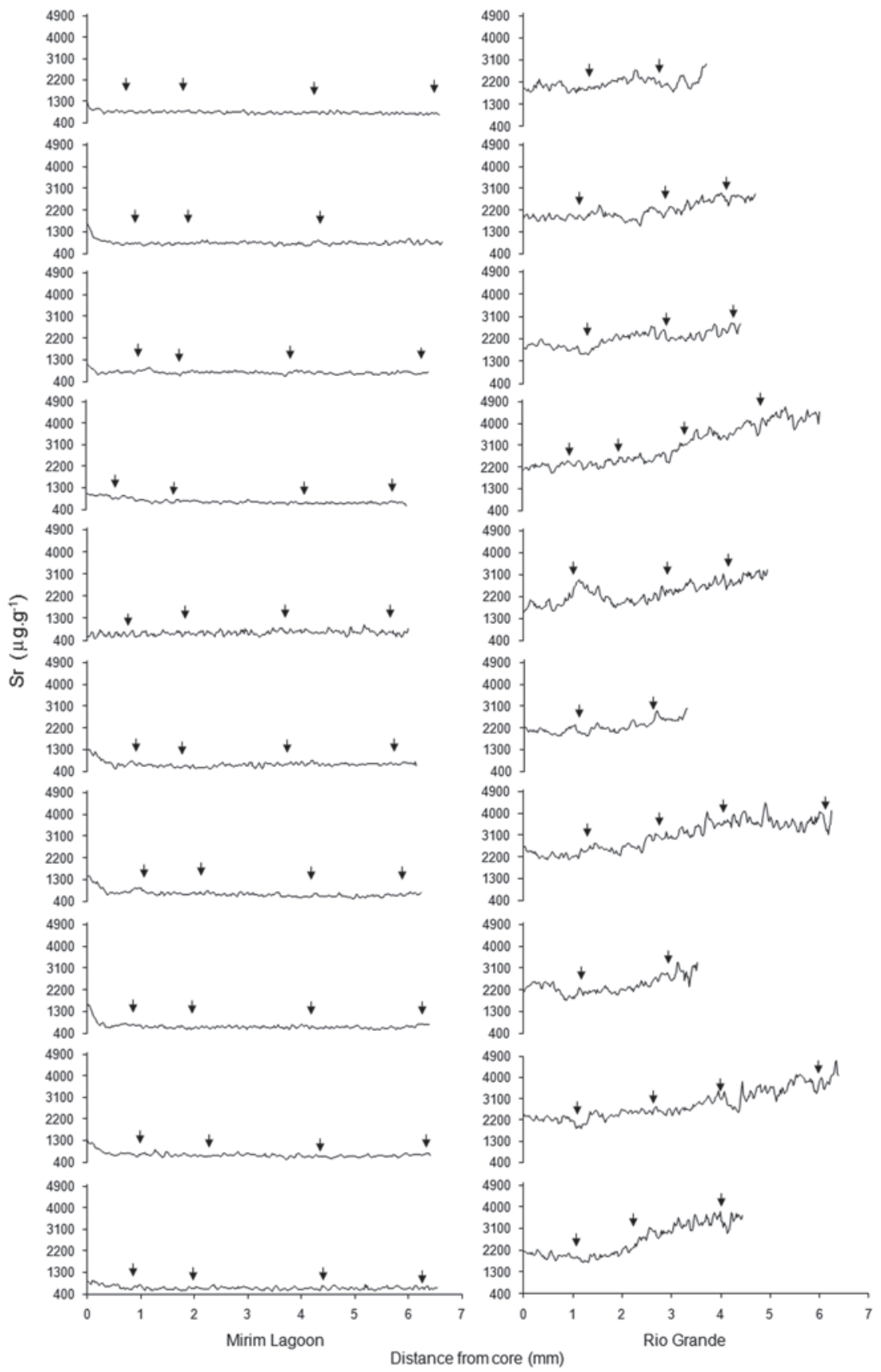

Fig. 3. Strontium concentrations along life-history profiles for individual otoliths of Micropogonias furnieri. The arrows indicate the location of the 1, 5, 20, and 35 ${ }^{\text {th }}$ annuli for specimens of the Mirim Lagoon (left), and 1, 5, 10, and 20 ${ }^{\text {th }}$ annuli for the Rio Grande (right) individuals.

\section{Sr and Ba chronological patterns}

Strontium concentrations for otoliths of $M$. furnieri from the marine environment showed increasing trends with age along the life-history profiles. However, the fact that strontium showed no significant declines throughout the life-history of marine fish clearly indicates that they spent their lives in a marine dominated environment and did not enter freshwater. Although salinity and its relationship with ambient strontium concentrations is believed to be the most consistent explanatory factor for variable strontium levels in otoliths, other factors including growth rate (Sadovy \& Severin, 1994), temperature (Fowler et al., 1995a) and ontogeny (Fowler et al., 1995b; Brown \& Severin, 2009) can potentially influence Sr uptake into otoliths. It is possible that the increasing strontium trend displayed in marine $M$. furnieri otoliths could be at least partially related to these endogenous factors. Temperature has also been reported to relate to variation in otolith strontium (Fowler et al., 1995a; Martin et al., 2004; 


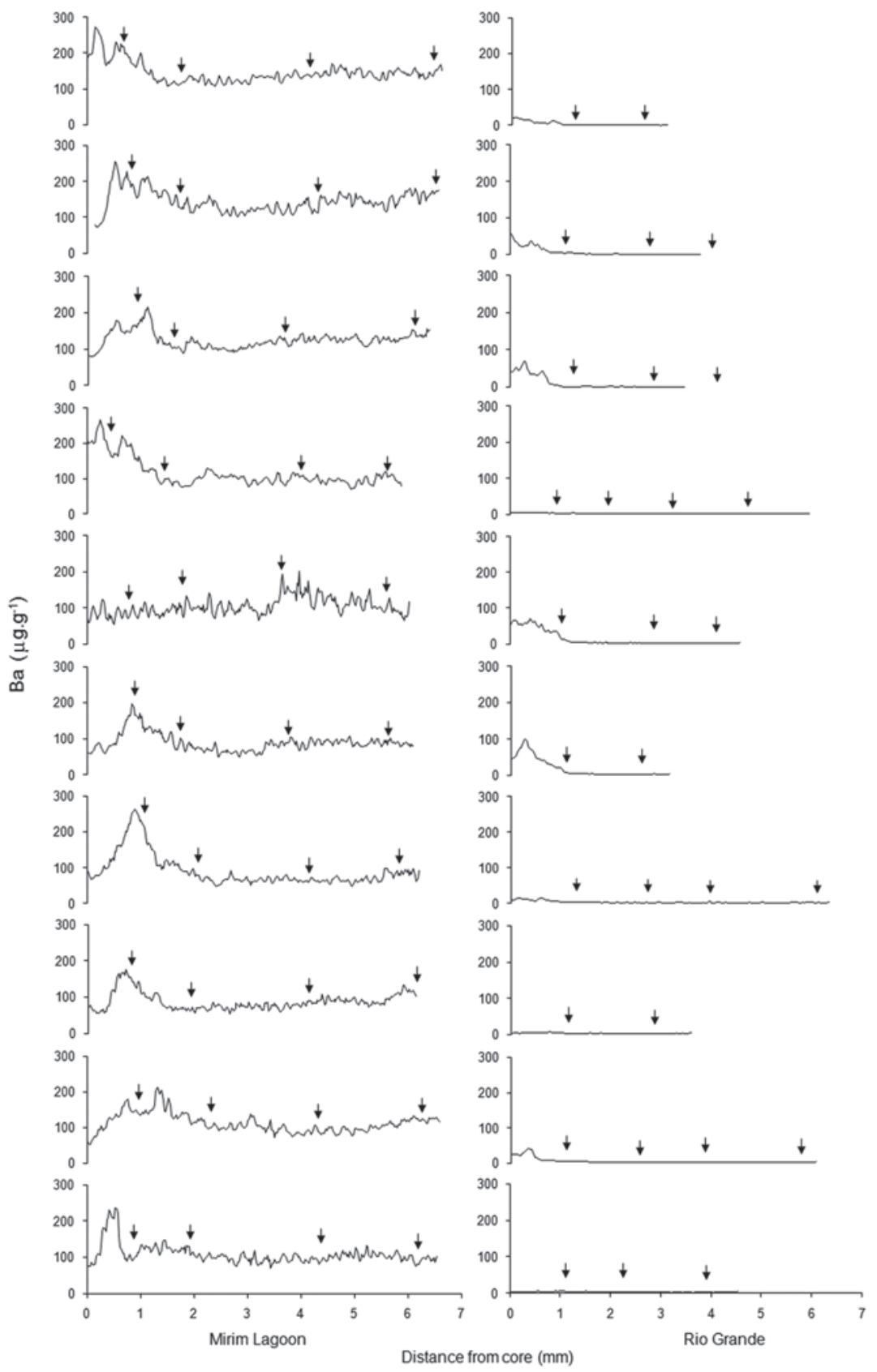

Fig. 4. Barium concentrations along life-history profiles for individual otoliths of Micropogonias furnieri. The arrows indicate 1, 5, 20, and $35^{\text {th }}$ annuli for specimens of the Mirim Lagoon (left), and 1, 5, 10, and $20^{\text {th }}$ annuli for the Rio Grande (right) individuals.

Martin \& Wuenschel, 2006), although in this case temperature should not be important in influencing the strong differences between the marine and freshwater fish because both the inshore marine and Mirim Lagoon environments experience similar seasonal temperature variations of approximately 9 to $22^{\circ} \mathrm{C}$ (Piola et al., 2008; M. Burns, pers. comun.).

Notably, in contrast to the marine samples, there was no increasing trend in strontium incorporation with age for the samples from Mirim Lagoon, which suggests that ontogenetic influences were unlikely responsible for the observed $\mathrm{Sr}$ trends. Growth rate has also been suggested to negatively correlate with incorporation of Sr into otoliths of Epinephelus guttatus Linnaeus (Sadovy \& Severin, 1994), which could explain the increasing trend with age for the marine samples. In another study, growth rate effects on strontium incorporation were not established for otoliths of juveniles of another sciaenid fish Leiostomus xanthurus Lacepède (Bath et al., 2000), although it should be recognized that variation in growth rate for juveniles is likely much less than across life-history profiles of adults. While we can not clearly explain the differences in the life-history trends of strontium incorporation between freshwater and marine samples, these 


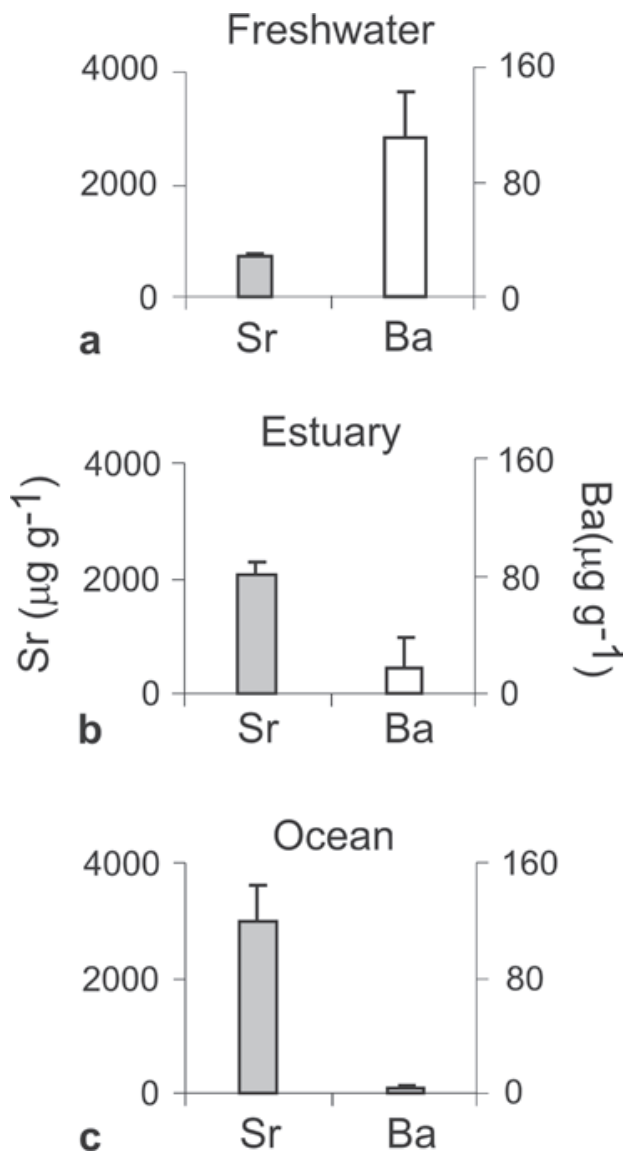

Fig. 5. Reference strontium and barium mean concentrations on otoliths of Micropogonias furnieri calculated for freshwater (a) and coastal (c) environments and estimated for the Patos Lagoon Estuary (b).

differences should not confound our ability to infer periods of marine and freshwater residency from otolith strontium.

Otolith barium profiles in both marine and freshwater samples showed well defined peaks within the first year of life after which barium concentrations decreased to very low levels $\left(<5 \mu \mathrm{g} \mathrm{g}^{-1}\right)$ for otoliths from marine fish, but only decreased to concentrations of about $100 \mu \mathrm{g} \mathrm{g}^{-1}$ for freshwater fish. Despite the major differences in otolith barium concentrations between freshwater and marine fish, the occurrence of barium peaks within the first year of life was consistent among otoliths from both environments. These consistent barium peaks were, however, not matched by drops in strontium during the first year of life, which would be consistent with residency in low salinity water during the early life period. This suggests that the barium peaks during the first year of life may not be entirely a result of residency in high barium, low salinity waters. Ontogenetically varying factors may be acting to influence incorporation of barium and strontium during the early life. These factors may include faster growth rates commonly observed during the early life of fishes, or the occurrence of an immature osmoregulatory system that stabilizes over time (Radtke, 1995). According to Ruttenberg et al. (2005), there is a trace metal enrichment (including barium) in the otolith core region for a variety of fish species, however, the barium peaks observed in our study extended for at least one year of life, well beyond the otolith core region.

The contradictory patterns of barium and strontium variation during the first year of life compared to the expectations based on the comparisons between marine and freshwater fish may complicate interpretations of fish movements from otolith barium for the early life stage. However, irrespective of the influence of endogenous processes on the early life history barium peaks, the magnitudes of the peaks did clearly vary between the Mirim Lagoon and marine otoliths which does suggests an environmental influence. Strontium concentrations were also much higher for the marine fish than the freshwater fish during the first year of life, consistent with the different salinity environments. It is therefore still possible that the magnitude of the barium peaks during the first year of life can be used to infer marine or freshwater residency, irrespective of the relatively constant strontium levels during this period. The constant strontium levels during the first year of life may reflect the fact the fish remained in a similar salinity environment and that strontium incorporation into the otoliths during the first year of life is not influenced by endogenous processes similar to those influencing barium incorporation.

\section{Implications for freshwater Micropogonias furnieri}

Some interesting information regarding the life cycle of M. furnieri from Mirim Lagoon has emerged from these results. Micropogonias furnieri collected in Mirim Lagoon were on average 35 years of age and there were no samples less than 32 years of age. This suggests that most fish in the lagoon were from a few cohorts that recruited to the lagoon over 30 years prior to sampling. Life-history profiles of barium and strontium in otoliths indicated that the fish in Mirim Lagoon entered the lagoon very early in their life history and have remained there for their entire lives as a trapped group. The dominance of the Mirim Lagoon group by a few cohorts of very old fish indicates a sustained failure of reproductive success for this group, and that few individuals have been able to enter the Mirim Lagoon for over 30 years. Recent samplings on Mirim Lagoon found eight 3-4 years old $M$. furnieri together with almost 100 individuals older than 32 years (Castello, pers. comun.), which corroborates the absence of significant stock renewal in that lagoon. About 32 years before our fish collections, a floodgate was built in the São Gonçalo channel, the only communication between the estuary of Patos Lagoon and Mirim Lagoon. Our results demonstrate that this closure was effective on preventing significant fish migration from estuarine and coastal regions of Rio Grande to Mirim Lagoon, and it is the most plausible explanation for the almost complete absence of young fish inside the lagoon. If $M$. furnieri could reproduce in the Mirim Lagoon, we would expect that lower strontium concentrations at the otolith core would be more common and an inversion of the age-structure (more young than old fish) should be evident. Previous studies indicate that $M$. furnieri reproduction and larval occurrence are associated with 
brackish water (Macchi \& Christiansen, 1992; Sinque \& Muelbert, 1997; Acha et al., 1999). Therefore, this species appears not capable of completing its life-cycle within the freshwater environment of the Mirim Lagoon. For this reason, we characterize the Mirim Lagoon M. furnieri as a trapped fish group and not as a population, since reproductive activity is one of the attributes defining the biological concept of population. Given that the floodgate has prevented significant fish movements between Mirim Lagoon and estuarine/coastal regions, and adding the effect of the local fishery activity, that fish group will probably be extinct in the near future.

\section{Acknowledgements}

This study was supported by Petrobrás, CNPq and a grant from the Inter-American Institute for Global Change Research (IAI) CRN 2076 which is supported by the US National Science Foundation (Grant GEO-0452325). CQA received a $\mathrm{PhD}$ fellowship from CNPq, and JHM a CNPq grant (Proc. 305969/2003-0). Special thanks to Valeria Bellotto (Center for Technology Earth and Ocean Science, UNIVALI), who prepared and provided the calibration standards used in this work. We also thank Luciano Fisher (Programa de PósGraduação em Oceanografia Biológica - FURG), who gently yielded the first version of the map presented on this study, Alvaro Pereira (PUC-RJ) for his assistance in LA-ICPMS analysis, and Randy J. Brown (U.S. Fish and Wildlife Service) for his helpful comments and conversations about this article. We would like to thank Paul Hamer and two anonymous referees for their dedicated reading and excellent suggestions that considerably improved the quality of this publication.

\section{Literature Cited}

Acha, E. M., H. Mianzan, C. Lasta \& R. A. Guerrero. 1999. Estuarine spawning of the whitemouth croaker Micropogonias furnieri (Pisces: Sciaenidae) in the Río de la Plata, Argentine. Marine and Freshwater Research, 50: 57-65.

Albuquerque, C.Q., J. H. Muelbert \& L. A. N. Sampaio. 2009. Early developmental aspects and validation of daily growth increments in otoliths of Micropogonias furnieri (Pisces, Sciaenidae) larvae reared in laboratory. Panamerican Journal of Aquatic Sciences, 4: 259-266.

Bath, G. E., S. R. Thorrold, C. M. Jones, S. E. Campana, J. W. McLaren \& L. W. H. Lam. 2000. Strontium and barium uptake in aragonitic otoliths of marine fish. Geochimica et Cosmochimica Acta, 64: 1705-1714.

Belotto, V. R. \& N. Miekeley. 2000. Improvements in calibration procedures for the quantitative determination of trace elements in carbonate material (mussel shell) by laser ablation ICP-MS. Freseniu's Journal of Analytical Chemistry, 367: 635-640.

Belotto, V. R. \& N. Miekeley. 2007. Trace metals in mussel shells and corresponding soft tissue samples: a validation experiment for the use of Perna perna shells in pollution monitoring. Analytical and Bioanalytical Chemistry, 389: 769-776.

Brazner, J. C., S. E. Campana, D. K. Tanner \& S. T. Schram. 2004. Reconstructing habitat use and wetland nursery origin of yellow perch from Lake Superior using otolith elemental analysis. Journal of the Great Lakes Research, 30: 492-507.
Brown, R. J. \& K. P. Severin. 2009. Otolith chemistry analyses indicate that water $\mathrm{Sr}$ :Ca is the primary factor influencing otolith $\mathrm{Sr}$ :Ca for freshwater and diadromous fish but not for marine fish. Canadian Journal of Fisheries and Aquatic Sciences, 66: 1790-1808.

Burns, M. D. M., A. M. Garcia, J. P. Vieira, M. A. Bemvenuti, D. M. L. Marques \& M. V. Condini. 2006. Evidence of habitat fragmentation affecting fish movement between the Patos and Mirim coastal lagoons in southern Brazil. Neotropical Ichthyology, 4: 69-72.

Campana, S. E. 1999. Chemistry and composition of fish otoliths: pathways, mechanisms and applications. Marine Ecology Progress Series, 188: 263-297.

Campana, S. E. \& J. D. Neilson. 1985. Microstructure of fish otolith. Canadian Journal of Fisheries and Aquatic Sciences, 42: 10141032.

Campana, S. E., A. Valentin, J. M. Sévigny \& D. Power. 2007. Tracking seasonal migrations of redfish (Sebastes spp.) in and around the Gulf of St. Lawrence using otolith elemental fingerprints. Canadian Journal of Fisheries and Aquatic Sciences, 64: 6-18.

Castello, J. P. 1986. Distribucion, crecimiento y maduracion sexual de la corvina juvenile (Micropogonias furnieri) en el estuario de la Lagoa dos Patos, Brasil. Physis, 44: 21-36.

Castello, J. P. \& O. O. Möller. 1978. On the relationship between rainfall and shrimp production in the estuary of Patos Lagoon (Rio Grande do Sul, Brasil). Atlântica, 3: 67-74.

Elsdon, T. S. \& B. M. Gillanders. 2002. Interactive effects of temperature and salinity on otolith chemistry: Challenges for determining environmental histories of fish. Canadian Journal of Fisheries and Aquatic Sciences, 59: 1796-1808.

Fowler, A. J., S. E. Campana, C. M. Jones \& S. R. Thorrold. 1995a. Experimental assessment of the effect of temperature and salinity on elemental composition of otoliths using solution-based ICPMS. Canadian Journal of Fisheries and Aquatic Science, 52: 1421-1430.

Fowler, A. J., S. E. Campana, C. M. Jones \& S. R. Thorrold. 1995b. Experimental assessment of the effect of temperature and salinity on elemental composition of otoliths using laser ablation ICPMS. Canadian Journal of Fisheries and Aquatic Science, 52: 14311441.

Gillanders, B. M. 2005. Otolith chemistry to determine movements of diadromous and freshwater fish. Aquatic Living Resources, 18: $291-300$

Gillanders, B. M. \& M. J. Kingsford. 2000. Elemental fingerprints of otoliths of fish may distinguish estuarine 'nursery' habitats. Marine Ecology Progress Series, 201: 273-286

Gillanders, B. M. \& M. J. Kingsford. 2003. Spatial variation in elemental composition of otoliths of three species of fish (family Sparidae). Estuarine, Coastal and Shelf Science, 56: 1-16.

Hamer, P. A. \& G. P. Jenkins. 2007. Comparison of spatial variation in otolith chemistry of two fish species and relationships with water chemistry and otolith growth. Journal of Fish Biology, 71: 1035-1055.

Hamer, P. A., G. P. Jenkins \& P. Coutin. 2006. Barium variation in Pagrus auratus (Sparidae) otoliths: A potential indicator of migration between an embayment and ocean waters in south-eastern Australia. Estuarine, Coastal and Shelf Science, 68: 686-702.

Hoolihan, J. P. 2006. Age and growth of indo-pacific sailfish, Istiophorus platypterus, from the Arabian Gulf. Fisheries Research, 78: 218-226.

Jacquet, S. H. M., F. Dehairs, D. Cardinal, J. Navez \& B. Delille. 2005. Barium distribution across the Southern Ocean frontal system in the Crozet-Kerguelen Basin. Marine Chemistry, 95: 149-162. 
Jaureguizar, A. J., J. Bava, C. R. Carozza \& C. Lasta. 2003. Distribution of the whitemouth croaker (Micropogonias furnieri) in relation to environmental factors at the Rio de la Plata estuary, South America. Marine Ecology Progress Series, 255: 271-282.

Jaureguizar, A. J., M. I. Militelli \& R. A. Guerrero. 2008. Environmental influence on maturity stage spatial distribution of whitemouth croaker (Micropogonias furnieri) along an estuarine gradient. Journal of the Marine Biology Association of the United Kingdon, 88: 175-181.

Lasta, C. A. \& E. M. Acha. 1996. Cabo de San Antônio: su importância en el patrón reproductivo de peces marinos. Frente Marítimo, 3: 39-46.

Lenaz, D., M. Miletic, E. Pizzul, S. Vanzo \& G. Adami. 2006. Mineralogy and geochemistry of otoliths in freshwater fish from Northern Italy. European Journal of Mineralogy, 18: 143-148.

Macchi, G. J., E. M. Acha \& C. A. Lasta. 1996. Desove y fecundidad de la corvina rubia Micropogonias furnieri Desmarest, 1823 del estuario del Río de la Plata, Argentina. Boletin del Instituto Espanol de Oceanografia, 12: 99-113.

Macchi, G. J. \& H. E. Christiansen. 1992. Estudio histológico del ciclo reproductivo en hembras de la corvina rubia (Micropogonias furnieri). Análisis de la estructura madurativa en distintas localidades del area bonaerense. Frente Marítmo, 11: 47-56.

Martin, G. B., S. R. Thorrold \& C. M. Jones. 2004. Temperature and salinity effects on strontium incorporation in otoliths of larval spot (Leiostomus xanturus). Canadian Journal of Fisheries and Aquatic Sciences, 61: 34-42.

Martin, G. B. \& M. J. Wuenschel. 2006. Effect of temperature and salinity on otolith element incorporation in juvenile gray snapper Lutjanus griseus. Marine and Ecology Progress Series, 324: 229-239.

Muelbert, J. H. \& G. Weiss. 1991. Abundance and distribution of fish larvae in the channel area of the Patos Lagoon Estuary, Brazil. NOAA Technical Report NMFS, 95: 43-54.

Pannela, G. 1971. Fish otoliths, growth layers and periodical patterns, Science, 173: 1124-1127.

Piola, A. R., O. O. Möller, R. A. Guerrero \& E. J. D. Campos. 2008. Variability of the subtropical shelf front off eastern South America: Winter 2003 and summer 2004. Continental Shelf Research, 28: 1639-1648.

Radtke, R. L. 1984. Cod fish otoliths: information storage structures. Flodevigen Rapportser, 1: 273-298.

Radtke, R. L. 1995. Otolith microchemistry of charr - use in life history studies. Nordic Journal of Freshwater research, 71: 392-395.

Reibisch, J. 1899. Ueber die Anzahl bei Pleuronectes platessa und die Altersbestimmung dieser Form aus den Otolithen. Wissenschaftliche Meeresuntersuchungen, 4: 233-248.

Rooker, J. R., D. H. Secor, V. S. Zdanowicz, G. De Metrio \& L. O. Relini. 2003. Identification of Atlantic bluefin tuna (Thunnus thynnus) stocks from putative nurseries using otolith chemistry. Fisheries Oceanography, 12: 75-84.

Rooker, J. R., D. H. Secor, V. S. Zdanowicz, L. O. Relini, N. Santamaria, M. Deflorio, G. Palandri \& M. Relini. 2002. Otolith elemental fingerprints of Atlantic bluefin tuna from eastern and western nurseries. ICCAT Collective Volume of Scientific Papers, 54: 498-506.

Ruttenberg, B. I., S. L. Hamilton, M. J. H. Hickford, G. L. Paradis, M. S. Sheehy, J. D. Standish, O. Ben-Tzvi \& R. R. Warner. 2005. Elevated levels of trace elements in cores of otoliths and their potential for use as natural tags. Marine and Ecology Progress Series, 297: 273-281.
Sadovy, Y. \& K. P. Severin. 1994. Elemental patterns in red hind (Epinephelus guttatus) otoliths from Bermuda and Puerto Rico reflected growth rate, not temperature. Canadian Journal of Fisheries and Aquatic Sciences, 51: 133-141.

Schwingel, P. R. \& J. P. Castello. 1990. Validación de la edad y el crecimiento de la corvina (Micropogonias furnieri) en el sur de Brasil. Frente Maritimo, 7: 19-27.

Secor, H. D., S. E. Campana, V. S. Zdanowicz, W. H. Lam, L. Yang, \& J. R. Rooker. 2002. Inter-laboratory comparison of Atlantic and Mediterranean bluefin tuna otolith micro constituents. ICES Journal of Marine Science, 59: 1294-1304.

Secor, D. H. \& J. R. Rooker. 2000. Is otolith strontium a useful scalar of life cycles in estuarine fishes? Fisheries Research, 46: 359-371.

Secor, H. D., J. R. Rooker, E. Zlokovitz \& V. S. Zdanowicz. 2001. Identification of riverine, estuarine, and coastal contingents of Hudson River striped bass based upon otolith elemental fingerprints. Marine Ecology Progress Series, 211: 245-253

Seeliger, U. 2001. The Patos Lagoon Estuary, Brazil. Pp. 167-183. In: Seeliger, U. \& B. Kjerfve (Eds.). Coastal Marine Ecossystems of Latin America Ecological Studies. Berlin, Springer-Verlag, 397p.

Sinque, C. \& J. H. Muelbert., J. H. 1997. Ictioplâncton. Pp. 134137. In: (Seeliger, U., C. Odebrecht \& J. P. Castello (Eds.). Ecossistemas costeiro e marinho do extremo sul do Brasil. Rio Grande, Editora Ecoscientia, 394p.

Surge, D. \& K. C. Lohmann. 2002. Temporal and spatial differences in salinity and water chemistry in SW Florida estuaries: effects of human-impacted watersheds. Estuaries, 25: 393-408.

Swearer, S. E., G. E. Forrester, M. A. Steele, A. J. Brooks \& D. W. Lea. 2003. Spatio-temporal and interspecific variation in otolith trace-elemental fingerprints in a temperate estuarine fish assemblage. Estuarine, Coastal and Shelf Science, 56: 1111-1123.

Vasconcellos, M. \& M. Haimovici. 2006. Status of white croaker Micropogonias furnieri exploited in southern Brazil according to alternative hypotheses of stock discreetness. Fisheries Research, 80: 196-202.

Vazzoler, G. 1975. Distribuição da fauna de peixes demersais e ecologia dos Sciaenidae da plataforma continental brasileira, entre as latitudes $29^{\circ} 21^{\prime} S$ (Torres) e $33^{\circ} 41^{\prime} S$ (Chuí). Boletim do Instituto Oceanográfico, 24: 85-169.

Vazzoler, A. E. A., L. S. H. Soares \& P. T. M. Cunningham. 1999. Ictiofauna da costa brasileira. Pp. 424-467. In: Lowe-McConnel, R. H. (Ed.). Estudos de Comunidades de Peixes Tropicais. São Paulo, Edusp, 535p.

Veinott, G. \& R. Porter. 2005. Using otolith microchemistry to distinguish Atlantic salmon (Salmo salar) parr from different natal streams. Fisheries Research, 71: 349-355.

Vries, M. C., B. M. Gillanders \& T. Elsdon. 2005. Facilitation of barium uptake into fish otoliths: influence of strontium concentration and salinity. Geochimica et Cosmochimica Acta, 69: 4061-4072.

Accepted April 25, 2010 Published June 25, 2010 